\title{
Long-term shoreline shifts on continental blocks during the Bajocian: an updated interpretation based on synthetic stratigraphical and palaeogeographical developments on regional scales
}

\author{
Dmitry A. Ruban ${ }^{1,2 *}$, Emad S. Sallam ${ }^{3}$ \\ ${ }^{1}$ Cherepovets State University, Sovetskiy Avenue 10, Cherepovets, Vologda Region, 162600 Russia \\ ${ }^{2}$ P.O. Box 7333, Rostov-na-Donu, 344056 Russia \\ ${ }^{3}$ Department of Geology, Faculty of Science, Benha University, Farid Nada Street 15, Benha 13518, Egypt \\ *corresponding author, e-mail: ruban-d@mail.ru
}

\begin{abstract}
Available reconstructions of Jurassic global sea level changes differ and are in need of an update. New stratigraphical charts and palaeogeographical developments for a number of large continental blocks or their portions of these (e.g., Germany, India, northeast Africa, northwest Australia, the Russian Platform and western Siberia) reveal regional longterm shoreline shifts (i.e., transgressions and regressions) during the Bajocian Stage (168.3-170.3 Ma). A comparison of these allows to document only a single coherent feature, namely the earliest Bajocian transgression, in the majority of the continental blocks considered. Undoubtedly, this event was triggered by a eustatic rise. However, long-term shoreline shifts were either weak to absent or differed between the blocks during almost the entire Bajocian, thus providing evidence of the apparent stability of global sea level and the importance of regional tectonic activity as a control mechanism on particular transgressions and regressions. Interestingly, it appears that the earliest Bajocian eustatic rise was a constituent of a long-term eustatic pattern; the nature of this event has yet to be fully understood. Generally, the findings presented here are in better agreement with Anthony Hallam's view of Jurassic eustasy and question some other global sea level reconstructions.
\end{abstract}

Key words: Bajocian, eustasy, Middle Jurassic, platform, transgression

\section{Introduction}

Reconstructions of global sea level (eustatic) changes in the geological past are of great importance for understanding the evolution of continental blocks, basin development, palaeoclimate dynamics and biotic transitions (and vice versa). In spite of significant progress since the late 1970s, our knowledge of eustatic fluctuations remains incomplete and somewhat uncertain (Ruban, 2016). Not only is this the case for Precambrian or Palaeozoic time spans, but also for much younger intervals, such as the Jurassic Period that has been studied in great detail. Two main alternative reconstructions of Jurassic global sea level changes were proposed by Hallam (1978, 1988) and Haq et al. (1987), respectively. Both of these have been updated subsequently, by Hallam (2001) and Haq \& Al-Qahtani (2005), respectively, with further reinterpretation by Ruban (2015). Finally, Haq (2018) presented another revised version of the Jurassic global sea level curve. These reconstructions (either in original or modified form) are 
actively being used in far-reaching interpretations (e.g., Boulila et al., 2018). Moreover, van der Meer et al. (2017) have recently proposed yet another reconstruction, which is of low resolution, but sufficiently accurate to allow judgements on Jurassic eustasy to be made. Ruban \& Sallam (2016, 2018) presented new evidence that, generally, was in support of Hallam's views, although it became clear that further consideration of as many 'fresh' data as possible is called for to understand Jurassic global sea level changes.

In a previous paper, Ruban \& Sallam (2018) drew conclusions on the absence of a long-term eustatic lowstand during the first stage of the Middle Jurassic, i.e., the Aalenian. They also presented some preliminary evidence of a widespread transgression during the Bajocian. If the latter prove to be correct, this is really significant when the short duration (2 myr) of this second stage of the Middle Jurassic (Gradstein et al., 2012; Ogg et al., 2016; Wiggan et al., 2018) is taken into account. Hypothetically, such a transgression could be related to a global sea level rise. Ruban's (2015) interpretation raises doubts over a eustatic rise during the Bajocian, and this concern is supported by data supplied by Ruban \& Sallam (2016) for northeast Africa, which also implies the doubtful nature of such a rise. Below, we attempt to update current knowledge on long-term shoreline shifts on major continental blocks during the Bajocian. The long-term (of stage length) pattern is emphasised because this is the sole one that can be correlated on a near-global scale. Continental blocks are chosen so to minimise the outstanding influence of tectonic factors on active margins and to deal with 'flat' domains where shoreline shifts were sufficiently broad to be well documented.

\section{Materials and method}

Global sea level changes can be documented using three principal approaches, namely in-depth examination of any regional record of global representativeness (e.g., Miller et al., 2005), modelling based on tectonic and/or geochemical proxies (e.g., Müller et al., 2008) and near-global comparisons (constrained by accurate stratigraphical correlations) of multiple regional records. The importance and efficacy of the last-named approach was demonstrated, in particular, by Hallam (2001), Miall (2010) and Ruban \& Sallam (2018). In fact, all three approaches have the same objective in common, namely a correct reconstruction of global sea level changes, but all have certain limitations. The first approach cannot fully steer clear from the influence of regional tectonic activity, even if this is minor. The second approach employs the single factor of eustasy, the importance of which changed through geological time, while the third appears to be most reliable, although the outcome of its application depends strongly on the proper choice of regional reference records. As a result, our views of Phanerozoic eustasy remains strongly biased and 'chaotic' (Ruban, 2016). The present study focuses on transgressions and regressions on continental blocks as appropriate reflectors of eustatic changes. Although shoreline shifts can be influenced by some regional tectonic activity, their coherence for several large and tectonically distinct domains can be taken as evidence of a planet-scale eustatic event.

For the purposes of the present study, regional stratigraphical records of several large continental blocks have been examined (Fig. 1). Laurasia (sensu Seton et al., 2012) is represented by the territory of present-day Germany, the Russian Platform and western Siberia; West Gondwana (sensu Seton et al., 2012) covers present-day northeast Africa and Arabia, while East Gondwana (sensu Seton et al., 2012) corresponds to India and northwest Australia. In view of the fact that the present paper aims to update current knowledge, only domains for which more or less 'fresh' data are available are here chosen for analysis. The regions analysed are fairly representative considering their location in different parts of the Middle Jurassic world (Fig. 1). The main data sources consulted for the present study are: Germany; Menning \& Hendrich (2016); the Russian Platform; Mitta (2012) and Ruban \& Sallam (2018); western Siberia; Kontorovitch et al. (2013); northeast Africa; Guiraud et al. (2005) and Ruban \& Sallam (2016); Arabia; Sharland et al. (2001) and Simmons et al. (2007); India; Raju (2007) and Pandey et al. (2009) and northwest Australia; Riding

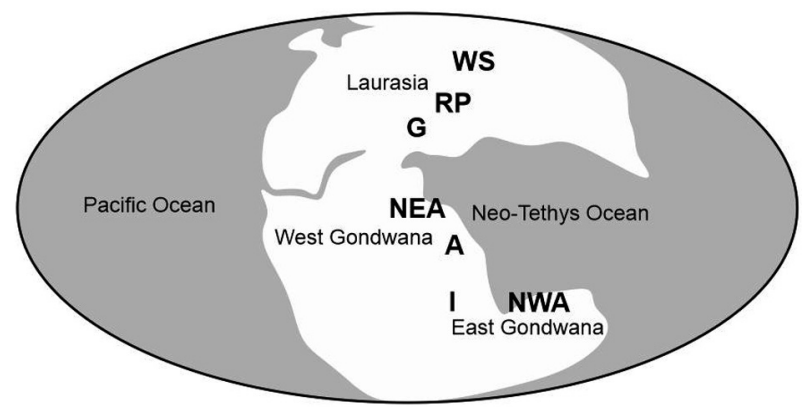

Fig. 1. Middle-Late Jurassic plate tectonic setting (simplified from Seton et al., 2012) and location of continental domains considered in the present paper. Abbreviations: A - Arabia, G - Germany, I - India, NEA - northeast Africa, NWA - northwest Australia, RP - Russian Platform, WS - western Siberia 
et al. (2010) and Tao et al. (2013). All of these are synthetic, region-scale stratigraphical and occasionally palaeogeographical updates of previously published information. However, such of vital importance in our understanding of the global extent of transgressions and regressions, as was documented by Hallam (2001). Even if these developments comprise both novel and previous data, the developments themselves are 'fresh' sources of updated information.

New and accurate composite regional stratigraphical charts that are provided in the sources mentioned above and, whenever available, detailed regional palaeogeographical reconstructions have been analysed in order to draw conclusions on direction (landward or seaward) and spatial extent of regional long-term shoreline shifts during the Bajocian. It should be stressed here that only those sources that have been used (i.e., stratigraphical charts and palaeogeographical reconstructions) are referred to in the present paper. The data proper are not discussed here so as to avoid unnecessary replication, although some principal comments that are relevant to interpretations of shoreline shifts on the basis of these are supplied here for clarity.

In the present study, transgressions and regressions are understood merely as land- and seaward shoreline shifts, respectively (compare Catuneanu, 2006). The mechanism of these events from a sequence-stratigraphical point of view (e.g., normal vs forced regression) is not considered for the purposes of the present analysis. Shoreline shifts should be clearly differentiated from deepening and shallowing phases and, thus, only synthetic regional data are informative on the former. Single-section or single-area records, if even detailed and novel, are unsuitable. This also explains why region-scale stratigraphical and occasionally palaeogeographical developments are preferred in the present paper.

Evidence from regional records is compared in order to document any coherence of transgressions/regressions. To this aim, regional records should be justified against the modern stratigraphical framework (Gradstein et al., 2012; Ogg et al., 2016). Possible errors may result from certain incompatibility and slightly different resolution of regional stratigraphical schemes. Such error does not attain more than a quarter or a third of the duration of a stage and, thus, it is insignificant for a discussion of long-term patterns. Importantly, ammonite-based biozonations are well developed and easily correlated for the Bajocian (being favoured by the degree of ammonite provincialism), which also minimises correlation-related errors. In the case of coherence, it is possible to draw conclusions on common, eustatically driven shoreline shifts. These can be justified to the standard ammonite-based zones of the Bajocian (Ogg et al., 2012), taking into account the average duration of the relevant transgressions or regressions in the regions compared. If no coherence is found, this implies either that the influence of regional tectonic activity predominated or that global sea level changes were too weak to overcome the tectonic factor. Indeed, not for all continental masses are novel stratigraphical and palaeogeographical developments available; terrestrial deposition dominated on some Gondwanan blocks and some continents (e.g., North and South America) were strongly affected by active processes on their margins. However, the regions selected for the purposes of the present study, which document different major tectonic domains across the globe, really appear to be representative of a near-global picture, if not a global one.

\section{Synopsis of regional evidence}

Several sedimentary basins existed in the territory of present-day Germany during the Middle Jurassic. Precise stratigraphical relationships of the formations differentiated are shown on a chart that has recently been published by the German Stratigraphic Commission (Menning \& Hendrich, 2016). According to this source, marine sedimentation here. After a short hiatus across the Aalenian-Bajocian transition in the southern part, marine environments were re-established, marking a broad transgression. Local hiatuses are found in Bajocian sedimentary successions in German basins. Generally, shoreline shifts postdating the earliest Bajocian were insignificant (Fig. 2), as suggested by the spatial distribution of marine and terrestrial settings. This picture can be complemented by evidence from the nearby territory of the Netherlands. The synthesis by Herngreen et al. (2003) indicated that there were no major changes in marine sedimentation since the Early Jurassic and up to the Bajocian; a certain landward shoreline shift during this stage was triggered by regional tectonic activity.

The Bajocian marks a kind of turning point in the Jurassic history of the Russian Platform, where either erosion or continental (subaerial) sedimentation prevailed until the Bajocian, whereas marine environments tended to predominate later. Following a chiefly non-depositional regime during the Aalenian (Ruban \& Sallam, 2018), marine conditions started to spread during the Bajocian. This process is illustrated by the composite stratigraphical chart 


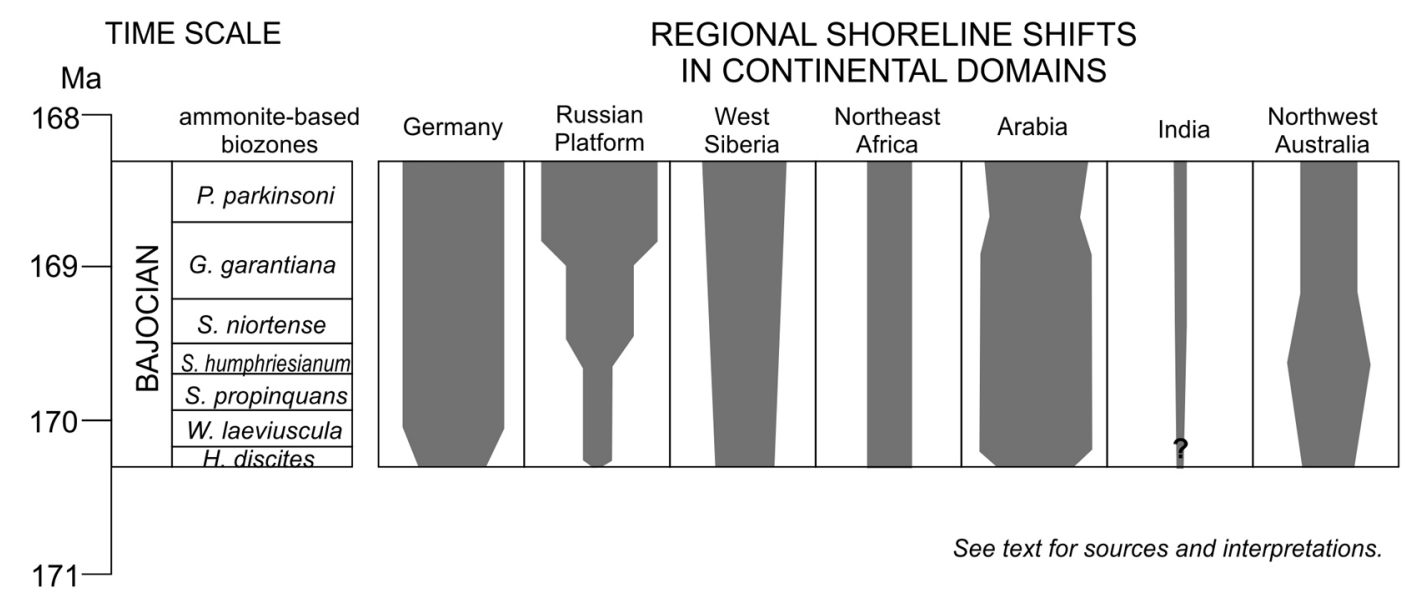

Fig. 2. Comparison of long-term Bajocian shoreline shifts on the continental domains considered here. The width of the grey area represents the extent of the transgression, whereas its shape is indicative of whether the process was gradual or not. The time scale follows Gradstein et al. (2012) and Ogg et al. (2016). Ammonite zones are indicated for general reference

that has been adopted and recently published by a group of leading Russian specialists (Mitta, 2012) and subsequently interpreted (for the Toarcian-Bajocian interval) by Ruban \& Sallam (2018). During the earliest Bajocian, transgression started in the eastern and southwestern parts of the platform, while the next pulse occurred during the middle Bajocian when marine conditions were established in the north and south. Finally, the sea penetrated the very centre of the platform during the late Bajocian, when nearly the entire platform was flooded. Generally, there is strong evidence of a pulsed, albeit unidirectional and markedly landward shoreline shift throughout the Bajocian (Fig. 2).

Kontorovitch et al. (2013) provided highly accurate palaeogeographical reconstructions of western Siberia during the Jurassic and were even able to quantify the area occupied by different facies. The territory covered by the sea increased during the Bajocian by $\sim 1.2$ times, in comparison to the Aalenian. Marine environments extended in the central part of this continental domain and the shoreline retreated southwards as a result of an ingression between the land masses of the Urals in the west and eastern Siberia in the east. Generally, there was a gradual transgression in western Siberia during the Bajocian (Fig. 2).

Both composite regional stratigraphical charts and palaeogeographical reconstructions (but not regional sea level reconstructions) (Guiraud et al., 2005) question the existence of major Bajocian transgressions or regressions in northeast Africa. Apparently, the shoreline occupied chiefly the same position in a long-term perspective. There were some important shoreline shifts during the late Early Jurassic, but the sea transgressed already during the Aalenian (Ruban \& Sallam, 2018). Moreover, the sea occupied the very northeasterly edge of the continent and somewhere the shoreline was located even more seawardly than the present day (Guiraud et al., 2005). Sedimentation remained generally the same during the Middle Jurassic. In neighbouring areas (e.g., southern Israel), there were minor shoreline shifts, as reflected by facies architecture in sedimentary successions, namely the early Bajocian transgression and the late Bajocian regression. Detailed analysis of two areas in Egypt, e.g., Gebel Maghara and Khashm El-Galala, has substantiated the notion of sea level stability during the Bajocian (Ruban \& Sallam, 2016). The slight changes in depositional environments established at Gebel Maghara by Abdelhady \& Fürsich (2015) do not provide evidence of broad shoreline shifts. Taken together, this evidence implies an absence of significant long-term transgressions or regressions in northeast Africa during the Bajocian (Fig. 2).

Marine deposition prevailed in Arabia during the Bajocian, and this region provides important evidence of shoreline shifts. The onset of the stage is marked by a regional maximum flooding surface (see Simmons et al., 2007, fig. 1), which constitutes the culmination of the transgression. More important considerations derive from a composite stratigraphical chart that was composed by Sharland et al. (2001), which indicates that a long-term transgression postdated a major regional unconformity. In some areas, this transgression started during the Toarcian, but in others (e.g., Oman) it set in later, i.e., during the Bajocian. Evidently, this transgression peaked in the first half of the latter stage. In spite of some local regressive episodes during the late Bajocian (Sharland et al., 2001), the shoreline 
remained more or less stable in Arabia throughout the greater part of this stage (Fig. 2).

Several sedimentary basins had evolved on the Indian (sub)continent since the Mesozoic but, as shown by the composite stratigraphical correlation chart of Raju (2007), deposition became widespread only during the Cretaceous. Marine environments were first established in the Kutch (Kachchh) Basin during the Bajocian when clastic and evaporite deposits of the Kala Dungar Formation accumulated (Raju, 2007). Recently, some other data have become available, as follows. Pandey et al. (2009) argued for a late Bajocian transgression in the Kachchh and Jaisalmer basins (see also Jain, 2012), while Basavaraju et al. (2016) interpreted transitional and occasionally marine deposits in the Bajocian of the Palar Basin. Finally, Rai et al. (2016) hypothesised that the marine transgression in the Jaisalmer Basin occurred earlier than the Bajocian. Taken together, this evidence is ambiguous somewhat, but it is generally clear that there was a weak landward shoreline shift in a few Indian basins during the middle Bajocian (Fig. 2). What remains unclear is whether or not this event was preceded by any significant transgression during the earliest Bajocian.

Riding et al. (2010) concluded on an early Bajocian transgression onto the western and northwestern margins of Australia, although their interpretation is in need of a certain justification for the older interval. Their notion was based on an analysis of the stratigraphical distribution of the Athol Formation in the Carnarvon Basin and the Newmarracarra Limestone in the onshore Perth Basin; moreover, those authors took important palaeobiogeographical evidence into account. Later, Tao et al. (2013) characterised the stratigraphical framework of the
North Carnarvon Basin in northwest Australia where shales of the Athol Formation had accumulated widely and continuously in a marine setting since the Early Jurassic. Progradation of the Legendre palaeodelta started during the middle Bajocian, reducing the area of marine sedimentation (Tao et al., 2013), and it is possible to conclude on a certain regression in the second half of this stage (Fig. 2).

\section{Interpretations}

Our comparison of regional records of Bajocian shoreline shifts on continental blocks allows to pinpoint both coherence and incoherence in patterns (Fig. 2). Coherence is observed during the early Bajocian (i.e., chiefly the interval of the $H$. discites ammonite Zone, as implied by some regional stratigraphical frameworks). The beginning of this stage coincided with a more or less significant transgression in the majority of the domains analysed here (Fig. 2). In contrast, the middle and late Bajocian shoreline shifts differed strongly between regions (Fig. 2). Importantly, they demonstrated a certain stability on several continental margins.

These observations suggest a near-global, eustatically driven transgression during the earliest Bajocian and a subsequent 'stabilisation' of global sea level (Fig. 3). The latter allowed regional tectonic activity to become the main controlling factor in regional shoreline shifts, which explains the difference observed in regional patterns for most of the stage. Indeed, there may be an alternative explanation, according to which eustatic rise continued during the Bajocian, but tectonic activation of continental margins was so strong as to override
TIME SCALE

$$
\mathrm{Ma}
$$

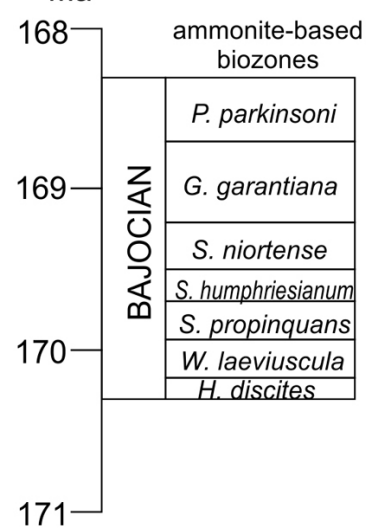

\section{GLOBAL SEA-LEVEL CHANGES}

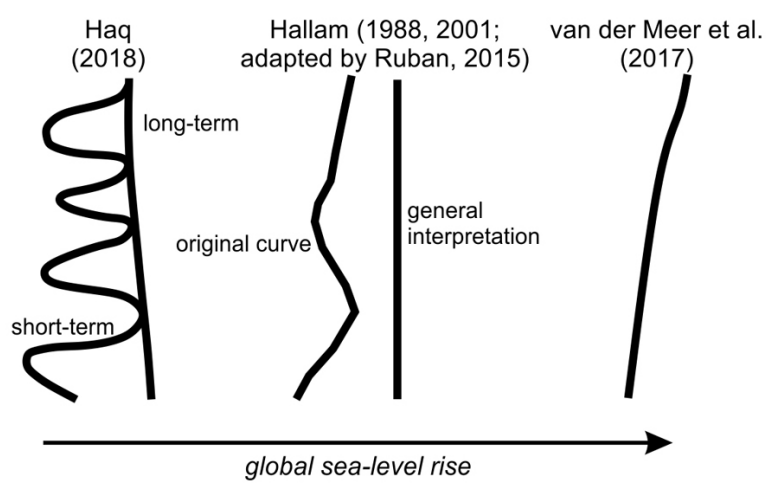

CLIMATE SHIFTS

Fig. 3. Alternative reconstructions of Bajocian global sea level changes in the light of the evidence presented herein (being derived from Figure 2; see also interpretations in the text). The time scale follows Gradstein et al. (2012) and Ogg et al. (2016). 
eustatic control. This explanation appears to be unrealistic in regard to the plate-tectonic setting of the domains considered (Seton et al., 2012) and the absence of such activity during the earliest Bajocian when a global sea level rise actually occurred.

Undoubtedly, the present paper suffers from the limitation linked to the absence of data on North and South America and Asia. However, such data either do not actually exist (e.g., because of missing marine deposits), are in need of an update or are derived from tectonically active regions. As a result, considering these would not strengthen the interpretations provided here. Most probably, the earlier reconstructions by Hallam (2001) and Haq (2018) were faced with the same limiting factor. Further investigations may permit to overcome this, but only with data based on 'stable' continental domains with marine sedimentation.

\section{Discussion}

Our interpretation of eustatic events during the Bajocian (Fig. 3) allows three additional inferences to be made. Firstly, the earliest Bajocian transgression was not only too short (see duration of relevant transgressions in regional records; Fig. 2), but also relatively moderate in strength. Otherwise, it would have resulted in a wider expansion of marine environments on the continents analysed (Fig. 2). A possible alternative explanation is that these land masses were relatively highly elevated, as a result of tectonic uplift or too low a global sea level prior to the Bajocian, or both. Secondly, these continents experienced some tectonic activity linked to processes along their margins (Seton et al., 2012) and/or dynamic topography processes, i.e., mantle influence on topography (Moucha et al., 2008; Lovell, 2010; Conrad, 2013). However, this activity was not too strong because the earliest Bajocian eustatic rise was able to override it. Thirdly, it is difficult to describe Bajocian global sea level changes either in a long-term or short-term frame. On the one hand, the eustatic rise that triggered transgressions on continents during the earliest Bajocian was a short-lived event. On the other hand, it should not be ignored on the longer time scale, because it marked a stage-level change in global sea level.

The evidence from the present work should be compared with available eustatic reconstructions. The earliest Bajocian transgression is not seen on the long-term curve proposed by Haq (2018); the long-term eustatic fall proposed by Haq or the gradual rise shown by van der Meer et al. (2017) are incompatible with the interpreted 'stability' of glob- al sea level (Fig. 3). The common earliest Bajocian transgression corroborates Hallam's (1978, 2001) idea of an early Bajocian eustatic rise, although evidence in favour of a late Bajocian rise cannot be found (Fig. 3). Finally, the 'stability' of shorelines is in full agreement with the interpretation published by Ruban (2015) of previous suggestions by Hallam (1988, 2001). Additionally, the interpretation presented here (Fig. 3) matches the earlier idea expressed by Hallam (1978), who suggested that the Jurassic global sea level experienced strong, yet short-term, rises followed by relative stability.

Three main outcomes can be based on these considerations. Firstly, Hallam's view of Bajocian eustasy is better supported by the new data than is Haq's interpretation. Secondly, the long-term global sea level rise during (almost) the entire Bajocian suggested by van der Meer et al. (2017) should not be confused with the earliest Bajocian eustatic rise. Thirdly, the weak long-term eustatic fall suggested by Haq (2018) is more closely comparable to the registered 'stability' than the rise suggested earlier by Haq \& Al-Qahtani (2005). If there was a kind of eustatic 'stability', it is not surprising that the interpretations have changed from a long-term rise (Haq \& Al-Qahtani, 2005) to a long-term fall (Haq, 2018).

The present analysis permits to pose two important questions for further research. Firstly, what caused the earliest Bajocian eustatic rise? Apparently, this should have been a relatively short, but globally strong tectonic event. Secondly, was the earliest Bajocian eustatic rise really a separate event? Hypothetically, the rise might have started already during the Aalenian, but it did not trigger a near-global transgression until the global sea level reached a critical point after which flooding of 'flat' continental surfaces became possible. Definitive answers on these questions appear impossible at this time; in contrast, the Bajocian 'stability' can be well explained by the more or less 'quiescent' tectonic evolution of the planet (Seton et al., 2012) and global warmth (Zalasiewicz \& Williams, 2012). From younger geological time intervals (e.g., the Paleocene), it is known that such conditions led to what can be provisionally referred to as eustasy stagnation (Ruban et al., 2010, 2012). In the case of the Jurassic, acceleration of Gondwana breakup and relevant plate tectonic processes led to a gradual rise of global sea level (see also Cogné et al., 2006). If so, eustacy stagnation would not exist. However, by definition, the tectonic processes noted were not that rapid, and on relatively brief geological time intervals such as the Bajocian Stage their influence was 'masked' by regional tectonic events. Short-term fluctuations of the global sea level as reconstructed by Haq (2018) could be nothing more 
than reflections of regionally restricted, tectonically driven variations in conditions of eustasy stagnation on a relatively short time scale.

Certain new data on Bajocian climate have to be considered as well. It has been established that sea water was relatively cool during the first half of this stage and warming occurred during the middle Bajocian (Korte et al., 2015; Wiggan et al., 2018). If this reflects the state of the global climate (Fig. 3), the latter was unfavourable for an earliest Bajocian transgression and eustasy stagnation can be hypothesised only for the late Bajocian. Linking these inferences to the considerations presented above requires special studies and additional tectonic and palaeoclimatic data.

\section{Conclusions}

Our analysis of evidence of Bajocian long-term shoreline shifts on several continental blocks in the light of new data allows three general conclusions to be drawn.

1. A coherence of regional transgressions is indicated on global sea level rise during the earliest Bajocian, whereas incoherence of regional shoreline shifts during most of the stage implies eustatic 'stability' when regional tectonic activity was responsible for different shoreline shifts in different domains.

2. Differentiation between short-term and longterm eustatic fluctuations during the Bajocian is not easy, because the earliest Bajocian global sea level rise was short, but comparable in rank to stage-long eustatic events.

3. Hallam's view of Bajocian global sea level changes (Hallam, 1978, 1988, 2001) is better supported by the new evidence than those expressed by Haq \& Al-Qahtani (2005), van der Meer et al. (2017) and Haq (2018).

The practical importance of these conclusions is evident and twofold. Firstly, a permanent update of our knowledge of global sea level curves leads to refinement and a better functioning in various geological studies, including those linked to hydrocarbon resource prospecting. Secondly, this knowledge has to be justified for a correct understanding of whether regional transgressions or regressions were driven by eustasy or by basin-scale tectonics. For instance, the stepwise Bajocian transgression onto the Russian Platform was likely controlled by subsidence in this domain, and not by any stagelong global sea level rise. Such conclusions are called for in order to understand the global context of regional events correctly and to propose further realistic interpretations with regard to sedimentation and palaeobiogeography.

\section{Acknowledgements}

We are grateful to both anonymous reviewers for helpful suggestions, as well as to W. Riegraf (Germany) for literature support.

\section{References}

Abdelhady, A.A. \& Fürsich, F.T., 2015. Sequence architecture of a Jurassic ramp succession from Gebel Maghara (North Sinai, Egypt): Implications for eustasy. Journal of Palaeogeography 4, 305-330.

Basavaraju, M.H., Jaiprakash, B.C., Chidambaram, L. \& Ayyadurai, M., 2016. Biostratigraphy and depositional environments of subsurface sediments in well Arani-A, Palar basin, Tamil Nadu. Journal of the Geological Society of India 88, 407-420.

Boulila, S., Laskar, J., Haq, B.U., Galbrun, B. \& Hara, N., 2018. Long-term cyclicities in Phanerozoic sea-level sedimentary record and their potential drivers. Global and Planetary Change 165, 128-136.

Catuneanu, O., 2006. Principles of Sequence Stratigraphy. Elsevier, Amsterdam. 375 pp.

Cogné, J.-P., Humler, E. \& Courtillot, V., 2006. Mean age of oceanic lithosphere drives eustatic sea-level change since Pangea breakup. Earth and Planetary Science Letters 245, 115-122.

Conrad, C.P., 2013. The solid earth's influence on sea level. Bulletin of the Geological Society of America 125, 1027-1052.

Gradstein, F.M., Ogg, J.G., Schmitz, M. \& Ogg, G. (Eds), 2012. The Geologic Time Scale 2012. Vols. 1-2. Elsevier, Oxford, 1176 pp.

Guiraud, R., Bosworth, W., Thierry, J. \& Deplanque, A., 2005. Phanerozoic geological evolution of Northern and Central Africa: An overview. Journal of African Earth Sciences 43, 83-143.

Hallam, A., 1978. Eustatic cycles in the Jurassic. Palaeogeography, Palaeoclimatology, Palaeoecology 23, 1-32.

Hallam, A., 1988. A re-evaluation of Jurassic eustasy in the light of new data and the revised Exxon curve. SEPM Special Publications 42, 261-273.

Hallam, A., 2001. A review of the broad pattern of Jurassic sea-level changes and their possible causes in the light of current knowledge. Palaeogeography, Palaeoclimatology, Palaeoecology 167, 23-37.

Haq, B.U., 2018. Jurassic sea-level variations: a reappraisal. GSA Today 28, doi: 10.1130/GSATG359A.1.

Haq, B.U. \& Al-Qahtani, A.M., 2005. Phanerozoic cycles of sea-level change on the Arabian Platform. GeoArabia 10, 127-160.

Haq, B.U., Hardenbol, J. \& Vail, P.R., 1987. Chronology of fluctuating sea levels since the Triassic. Science 235, 1156-1167. 
Herngreen, G.F.W., Kouwe, W.F.P. \& Wong, T.E., 2003. The Jurassic of the Netherlands. Geological Survey of Denmark and Greenland Bulletin 1, 217-229.

Jain, S., 2012. Integrated biostratigraphy and palaeoenvironment of the Middle Jurassic sediments at Kuldhar (Jaisalmer), Western India. Journal of the Palaeontological Society of India 57, 1-41.

Kontorovich, A.E., Kontorovich, V.A., Ryzhkova, S.V., Shurygin, B.N., Vakulenko, L.G., Gaideburova, E.A., Danilova, V.P., Kazanenkov, V.A., Kim, N.S., Kostyreva, E.A., Moskvin, V.I. \& Yan, P.A., 2013. Jurassic paleogeography of the Western Siberian sedimentary basin. Russian Geology and Geophysics 54, 747-779.

Korte, C., Hesselbo, S.P., Ullmann, C.V., Dietl, G., Ruhl, M., Schweigert, G. \& Thibault, N., 2015. Jurassic climate mode governed by oceanic gateway. Nature communications 6, 10015.

Lovell, B., 2010. A pulse of the planet: regional control of high-frequency changes in relative sea level by mantle convection. Journal of the Geological Society 167, 637-648.

Menning, M. \& Hendrich, A. (Eds), 2016. Stratigraphische Tabelle von Deutschland. GeoForschungZentrum, Potsdam, 1 chart.

Miall, A.D., 2010. The geology of stratigraphic sequences. Springer, Berlin, 522 pp.

Miller, K.G., Kominz, M.A., Browning, J.V., Wright, J.D., Mountain, G.S., Katz, M.E., Sugarman, P.J., Cramer, B.S., Christie-Blick, N. \& Pekar, S.F., 2005. The Phanerozoic Record of Global Sea-Level Change. Science 310, 1293-1298.

Mitta, V.V. (Ed.), 2012. Unifitsirovannaja regional'naja stratigrafitcheskaja skhema jurskikh otlozhenij Vostotchno-Evropejskoj platformy. Ob'jasnitel'naja zapiska. PIN RAN, Moskva, 64 pp. (in Russian)

Moucha, R., Forte, A.M., Mitrovica, J.X., Rowley, D.B., Quere, S., Simmons, N.A. \& Grand, S.P. 2008. Dynamic topography and long-term sea-level variations: There is no such thing as a stable continental platform. Earth and Planetary Science Letters 271, 101-108.

Müller, R.D., Sdrolias, M., Gaina, C., Steinberger, B. \& Heine, C., 2008. Long-Term Sea-Level Fluctuations Driven by Ocean Basin Dynamics. Science 319, 13571362.

Ogg, J.G., Ogg, G.M. \& Gradstein, F.M., 2016. A concise geologic time scale 2016. Elsevier, Amsterdam, 234 pp.

Pandey, D.K., Fürsich, F.T. \& Sha, J.G., 2009. Interbasinal marker intervals - A case study from the Jurassic basins of Kachchh and Jaisalmer, western India. Science in China Series D: Earth Sciences 52, 1924-1931.

Rai, J., Bajpai, S., Kumar, R., Singh, A., Kumar, K. \& Prakash, N., 2016. The earliest marine transgression in western India: New insights from calcareous nannofossils from Lathi Formation, Jaisalmer Basin. Current Science 111, 1631-1639.

Raju, D.S.N. (Ed.), 2007. Stratigraphic Mega Charts for the Indian Subcontinent. International Commission on Stratigraphy.

Riding, J.B., Westermann, G.E.G. \& Darbyshire, D.P.F., 2010. New evidence for the age of the Athol Formation
(Middle Jurassic; Bajocian) in the Tusk-1 and Tusk-2 wells, offshore Carnarvon Basin, Western Australia. Alcheringa 34, 21-35.

Ruban. D.A., 2015. Mesozoic long-term eustatic cycles and their uncertain hierarchy. Geoscience Frontiers 6, 503-511.

Ruban, D.A., 2016. A "chaos" of Phanerozoic eustatic curves. Journal of African Earth Sciences 116, 225-232.

Ruban, D.A. \& Sallam, E.S., 2016. Bajocian-Bathonian (Middle Jurassic) sea-level changes in northeastern Egypt: Synthesis and further implications. Journal of African Earth Sciences 120, 181-185.

Ruban, D.A. \& Sallam, E.S., 2018. The assumed Aalenian stage-long eustatic lowstand did not exist: A review of the fresh evidence from Africa and other continents. Journal of African Earth Sciences 139, 232-240.

Ruban, D.A., Zorina, S.O. \& Conrad, C.P., 2010. No global-scale transgressive-regressive cycles in the Thanetian (Paleocene): Evidence from interregional correlation. Palaeogeography, Palaeoclimatology, Palaeoecology 295, 226-235.

Ruban, D.A., Zorina, S.O., Conrad, C.P. \& Afanasieva, N.I., 2012. In quest of Paleocene global-scale transgressions and regressions: constraints from a synthesis of regional trends. Proceedings of the Geologists' Association 123, 7-18.

Seton, M., Müller, R.D., Zahirovic, S., Gaina, C., Torsvik, T., Shephard, G., Talsma, G., Gurnis, M., Turner, M., Maush, S. \& Chandler, M., 2012. Global continental and ocean basin reconstructions since $200 \mathrm{Ma}$. Earth-Science Reviews 113, 212-270.

Sharland, P.R., Archer, R., Casey, D.M., Davies, R.B., Hall, S.H., Heward, A.P., Horbury, A.D. \& Simmons, M.D., 2001. Arabian Plate Sequence Stratigraphy. Oriental Press, Manama, 371 pp.

Simmons, M.D., Sharland, P.R., Casey, D.M., Davies, R.B. \& Sutcliffe, O.E., 2007. Arabian Plate sequence stratigraphy: Potential implications for global chronostratigraphy. GeoArabia 12, 101-130.

Tao, C., Bai, G., Liu, J., Deng, C., Lu, X., Liu, H. \& Wang, D., 2013. Mesozoic lithofacies palaeogeography and petroleum prospectivity in North Carnarvon Basin, Australia. Journal of Palaeogeography 2, 81-92.

van der Meer, D.G., van den Berg van Saparoea, A.P.H., van Hinsbergen, D.J.J., van de Weg, R.M.B., Godderis, Y., Le Hir, G. \& Donnadieu, Y., 2017. Reconstructing first-order changes in sea level during the Phanerozoic and Neoproterozoic using strontium isotopes. Gondwana Research 44, 22-34.

Wiggan, N.J., Riding, J.B., Fensome, R.A. \& Mattioli, E., 2018. The Bajocian (Middle Jurassic): A key interval in the early Mesozoic phytoplankton radiation. Earth-Science Reviews 180, 126-146.

Zalasiewicz, J. \& Williams, M., 2012. The Goldilocks planet: the four billion year story of Earth's climate. Oxford University Press, Oxford, 303 pp.

Manuscript received: 10 October 2018 Revision accepted: 8 February 2019 